\title{
PELATIHAN PEMBUATAN TAMAN DAN SERBUK TANAMAN OBAT DI TEMBALANG SEMARANG
}

\author{
Heny Kusumayanti*, Vita Paramita, Wahyuningsih, Rizka Amalia, Vynda Dindasari Siregar, \\ Basa Ulina br Simalango, Elin Siswati \\ Departemen Teknologi Dan Industri Sekolah Vokasi Universitas Diponegoro \\ Jl. Prof. Soedarto, SH, Kampus Undip Tembalang, Semarang, Indonesia 50275 \\ Email : henykusuma_yanti@yahoo.co.id
}

\begin{abstract}
Heny Kusumayanti, Vita Paramita, Wahyuningsih, Rizka Amalia, Vynda Dindasari Siregar, Basa Ulina br Simalango, Elin Siswati, explain that indonesia is a fertile country, many plants can grow, including medicinal plants, but until now it has not been utilized optimally, so there needs to be socialization and training for the community. Training on the Making of Parks and Medicinal Powder at the Islamic Boarding School of Nurul Hikmah In Tembalang Subdistrict, Semarang Municipality, is a transfer of knowledge and the application of appropriate technology to the community, especially in the Islamic Boarding School of Nurul Hikmah. Use of medicinal plants in addition to being consumed also for reforestation or decorating the home page. This training is able to provide education to students at the Islamic Boarding School Student Nurul Hikmah. The wisdom of how to plant, treat medicinal plants that are good and right.
\end{abstract}

Keywords: Tanaman obat; serbuk tanaman obat; pondok pesantren;

\section{PENDAHULUAN}

Indonesia adalah negeri yang subur dengan berbagai macam jenis tanaman, tanahnya yang subur, dimana banyak tumbuh berbagai macam jenis tanaman. Berbagai jenis tanaman yang tumbuh di Indonesia dapat digunakan untuk kehidupan seharihari. Buah-buahan, tanaman bunga, sayur-sayuran, tanaman obat dan lain-lain. Tanaman obat yang berkembang ada bermacam-macam, diantaranya : sirih, salam, pandan wangi, kunyit, lengkuas, serai, temu kunci, jahe, temulawak, dan lain-lain.

Masyarakat yang modern dewasa ini, lebih memilih untuk selalu hidup bersih dan sehat, tetapi ada juga yang belum sadar akan pentingnya hidup bersih dan sehat. Oleh karena itu diperlukan tentang sosialisasi akan arti pentingnya hidup sehat. Tim pengabdian pada masyarakat Sekolah Vokasi Undip melakukan sosialisasi dan pelatihan kepada masyarakat. Temanya adalah Pelatihan Pembuatan Taman Dan Serbuk Tanaman Obat Di Pondok Pesantren Mahasiswa Nurul Hikmah Di Kecamatan Tembalang, Kotamadya Semarang.

Tanaman obat banyak yang tumbuh dan berkembang di Indonesia, tetapi sampai saat ini pemanfaatannya belum maksimal. Oleh sebab itu perlu adanya kerjasama antara pemerintah, perguruan tinggi, sekolah, masyarakat, dan adanya peran swasta supaya tanaman obat bisa dimanfaatkan sekaligus dapat meningkatkan perekonomian. [1]

Bangsa Indonesia sudah sejak jaman dahulu memanfaatkan dan mengkonsumsi hasil alam untuk keperluan kehidupan sehari-hari, antara lain seperti tanaman obat, tetapi cara memanfaatkannya belum maksimal. Tanaman obat, sudah lama dicanangkan pemerintah, merupakan salah satu hasil alam yang digunakan sebagai obat untuk menyembuhkan beberapa macam penyakit. Orang Jawa mengenalnya sebagai jamu [2], [3].

Tanaman obat selain berfungsi sebagai obat dapat juga dimanfaatkan untuk kehidupan sehari-hari antara lain : salam dapat digunakan untuk mengobati sakit perut, mengurangi atau menghentikan buang air besar yang berlebihan; pandan wangi yang berfungsi sebagai aromaterapi, pengharum kue, dapat juga digunakan sebagai pewarna dan pengharum masakan; kunyit antara lain dapat dimanfaatkan untuk mengobati gatal dan kejang, dapat untuk mengurangi adanya pembengkakan selaput lendir di mulut, sakit maag, diare, penurun panas; sirih dapat dimanfaatkan sebagai obat batuk rejan, asam urat, ambein, jantung, disentri, masuk angin, keputihan, memperlancar darah, mimisan, nyeri otot dan persendian, stroke, panas, panas dalam, green antibiotic; kencur sebagai obat batuk [4], [5].

Diharapkan dengan adanya sosialisasi dan pelatihan ini dapat meningkatkan kesadaran akan pentingnya kesehatan, salah satu caranya dengan cara menanam tanaman obat dan mengkonsumsi tanaman obat. Selain itu dapat menghemat pengeluaran serta, mampu menambah pendapatan apabila tanaman dan serbuk tanaman obat tersebut dijual.

\section{METODE PENELITIAN}

Pelatihan Pembuatan Taman dan Serbuk Tanaman Obat di Pondok Pesantren Mahasiswa Nurul Hikmah Di Kecamatan Tembalang, Kotamadya Semarang ini dilakukan dengan cara : Membuat Taman dan Serbuk Tanaman Obat dengan cara yang mudah dipahami dan dilakukan sehingga masyarakat dapat langsung mempraktekkannya sendiri. Penggunaan tanaman obat ini selain untuk dapat dipergunakan sebagai bahan dalam kebutuhan sehari- 
hari, juga dapat dipasarkan sehingga bisa menambah pendapatan bagi masyarakat.

Pembuatan taman tanaman obat dengan cara melakukan survey lokasi, menyiapkan media tanam, pupuk, peralatan dan bahan yang akan di tanam, menanam tanaman obat pada pot bunga yang sebelumnya diberi media tanam dan pupuk, menata dan memberi tulisan pada tanaman obat.

Pembutan serbuk tanaman obat dengan cara menyiapkan alat dan bahan yang akan dipergunakan dalam pembuatan serbuk kunyit (pisau, blender, saringan atau kain saring), membersihkan kunyit dengan cara mencucinya dengan air yang mengalir, mengupas kulitnya kemudian mencuci hingga bersih, memblender kunyit kemudian tambahkan air, menyaring larutan kunyit dengan menggunakan kain saring/penyaring sehingga sari kunyit yang didapat terpisah dari ampasnya. Sari kunyit dapat di buat serbuk dengan cara tradisional, dapat juga dengan menggunakan granulator.
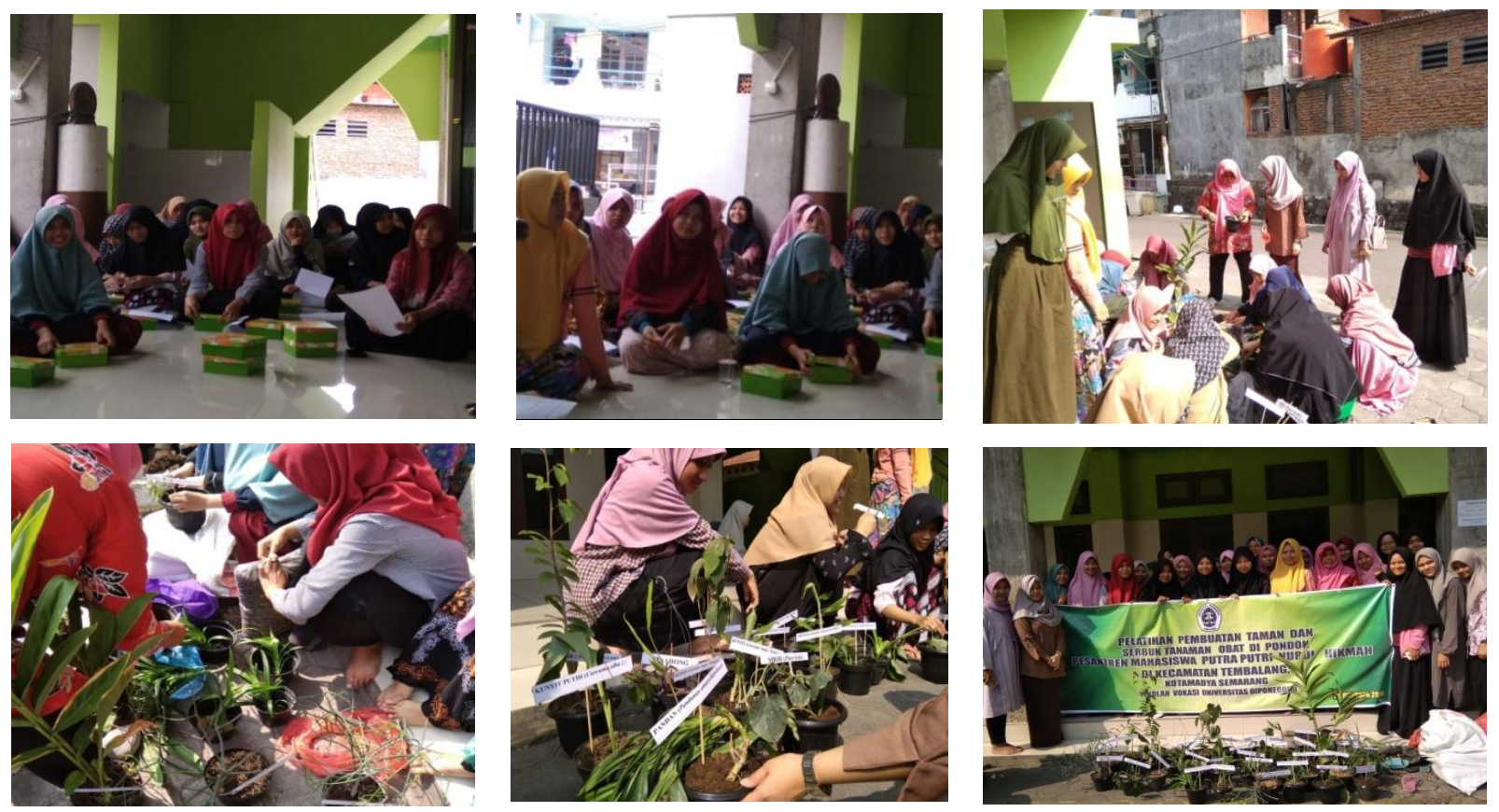
panaskan menggunakan api kecil, kalau diperlukan bisa ditambahkan gula pasir (sesuai selera) sambil dilakukan pengadukan secara kontinyu sampai mengering, apabila hasilnya menggumpal maka dihaluskan dan diayak supaya menghasilkan serbuk kunyit yang halus.

Dengan menggunakan granulator caranya memasukkan sejumlah air, kalau diperlukan bisa ditambahkan gula pasir kedalam granulator. Setelah campuran tersebut cukup homogen, masukkan larutan sari kunyit, dimana proses didalam glanulator kurang lebih selama 2 jam atau sampai terbentuk serbuk, untuk mendapatkan produk (serbuk) dengan ukuran homogen maka digunakan filter (saringan).

\section{HASIL DAN PEMBAHASAN}

Kesadaran akan pentingnya hidup bersih dan sehat harus ditanamkan sejak dini. Tim pengabdian pada masyarakat Sekolah Vokasi Undip melakukan

Gambar 1. Foto kegiatan

sosialisasi dan pelatihan kepada masyarakat, dengan tema Pelatihan Pembuatan Taman Dan Serbuk Tanaman Obat Di Pondok Pesantren Mahasiswa Nurul Hikmah Di Kecamatan Tembalang, Kotamadya Semarang. Dengan cara memberikan pengetahuan tentang pembuatan taman tanaman obat, cara aplikasi tentang pembuatan taman tanaman obat sehingga mempunyai manfaat lebih, memberikan cara aplikasi tentang pembuatan serbuk tanaman obat sehingga lebih bermanfaat dan mempunyai nilai jual lebih. Penanaman tanaman obat di Di Pondok Pesantren ini di taman di dalam pot, dikarenakan kurang adanya lahan pekarangan/lahan tanah untuk menaman. Halaman atau pekarangan rumah menjadi lebih bermanfaat, lebih ekonomis [6]. Prospek dari hasil pembuatan taman dan serbuk tanaman obat supaya dapat melestarikan lingkungan dengan cara membuat taman tanaman obat, dimana hasil dari taman tersebut selain untuk penghijauan juga bermanfaat sebagai apotik hidup, selain itu juga dengan membuat serbuk dari tanaman obat tersebut sehingga selain mempunyai umur simpan lebih lama, praktis kalau dikonsumsi, juga mempunyai nilai tambah lebih.

\section{KESIMPULAN}

Tanaman obat ditanam di dalam pot dan diberi nama sesuai nama tanamannya masing-masing. Karena kurang adanya lahan atau pekarangan, tanaman obat di tanam di dalam pot. Untuk memperpanjang umur simpan tanaman obat makanya 
dibuat serrbuk tanaman obat, selain itu juga praktis untuk dikonsumsi.

\section{DAFTAR PUSTAKA}

[1] Yulianto S. Pengetahuan Masyarakat Tentang Taman Obat Keluarga Di Nglinggi, Klaten Selatan. J Kebidanan Dan Kesehat Tradis 2016;1:100-44.

[2] Supardi S, Herman MJ, Yuniar Y. Penggunaan jamu buatan sendiri di Indonesia (analisis data riset kesehatan dasar tahun 2010). Bul Penelit Sist Kesehat 2011;14.

[3] Nurniswati N. Tanaman Obat Keluarga. Parapemikir J Ilm Farm 2015;3.

[4] Ningtias AF, Aisyah I., Pudjiastuti P. Manfaat Daun Sirih (Piper betle L.) Sebagai Obat Tradisional Penyakit Dalam di Kecamatan Kalianget Kabupaten Sumenep Madura. Artik Ilm Has Penelit Mhs 2014.

[5] Sari ID, Yuniar Y, Siahaan S, Riswati R, Syaripuddin M. Tradisi masyarakat dalam penanaman dan pemanfaatan tumbuhan obat lekat di pekarangan. Indones Pharm J 2015;5:123-32.

[6] Nugraha SP, Wanda Rusma A. Pelatihan Penanaman Tanaman Obat Keluarga. Seri Pengabdi Masy J Inov dan Kewirausahaan 2015;4. 